\title{
THE IMPORTANCE OF CENTRIFUGAL FORCE IN DETERMINING SEMEN CHARACTERISTICS
}

\author{
D. L. GARBERS AND N. L. FIRST \\ Department of Meat and Animal Science, University of Wisconsin, \\ Madison, Wisconsin, U.S.A.
}

(Received 25th Fuly 1970, revised 8th December 1970)

It is the purpose of this study to determine the effect of relative centrifugal force $(\mathrm{RCF}) \times g$ on various semen characteristics of the bull and boar.

Entire ejaculates of mature Yorkshire boars were collected and separated from the gel fraction by allowing the semen to run through three layers of cheesecloth into a warm thermos. The ejaculate was then placed in 50-ml centrifuge tubes and centrifuged at $1000 \mathrm{~g}$ for 10 or $15 \mathrm{~min}$ to remove the spermatozoa. Part of the first supernatant was kept for further analyses, while the remaining semen was centrifuged at forces and times given in Tables 1, 2 and 3. Bull epididymal fluid was collected by flushing through the vas deferens with a $154 \mathrm{~mm}-\mathrm{KCl}, 10 \mathrm{~mm}$-tris buffer at $\mathrm{pH} 7.2$ according to the method of Henle (1938). The sperm concentration in the epididymal fluid was adjusted to a concentration of about $10^{8}$ cells $/ \mathrm{ml}$ before centrifugation. Bull semen was obtained from American Breeders Service. The bull epididymal fluid and semen were handled as already described for the boar.

All centrifugations, except those at $105,000 \mathrm{~g}$, were in angle heads in 12-ml round-bottomed tubes. Each tube received $8 \mathrm{ml}$ of the sample, the upper $5 \mathrm{ml}$ being removed by pipette at the end of each centrifugation. The temperature was maintained at $15^{\circ} \mathrm{C}$, and all $\mathrm{RCF} \times \mathrm{g}$ values in the Tables represent the maximum force (bottom of centrifuge tube). The centrifugations at 105,000 $\mathrm{g}$, which were run on a Beckman model L with the 40 rotor, represent the force at the middle of the centrifuge tube.

Protein was measured by using the biuret reagent (Layne, 1957), and the nucleotide phosphatase according to the method described by Garbers, Wakabayashi \& Reed (1971). Phosphate was measured by adding $1 \mathrm{ml}$ of cold $10 \%$ trichloroacetic acid to $1 \mathrm{ml}$ of plasma, centrifuging at $12,000 \mathrm{~g}$ for 30 min and measuring phosphate in the supernatant by the method of Sumner (1944). Turbidity was measured at $560 \mathrm{~nm}$ (Mann, 1964).

The seminal plasma of Yorkshire boars shows considerable particulate contamination even after centrifuging at $105,000 \mathrm{~g}$ for $15 \mathrm{~min}$ (Table 1). Comparison of the $1000 \mathrm{~g}$ to the $105,000 \mathrm{~g}$ force shows a drop of $6 \mathrm{mg}$ in protein/ $\mathrm{ml}, 0.7$ in nucleotide phosphatase activity and 0.14 in $\mu \mathrm{mol}$ phosphate $/ \mathrm{ml}$ with the higher force. 
TABLE 1

THE EFFECT OF CENTRIFUGAL FORGE ON CHARAGTERISTICS OF BOAR SEMEN

\begin{tabular}{r|c|c|c|c|c}
\hline$R C F \times g$ & $\begin{array}{c}\text { Centrifuge } \\
\text { time (min) }\end{array}$ & $\begin{array}{c}\text { Absorbance } \\
\lambda \mathrm{n}=560\end{array}$ & Protein* & Phosphate $\dagger$ & $\begin{array}{c}\text { Nucleotide } \ddagger \\
\text { phosphatase }\end{array}$ \\
\hline 1,000 & 15 & 1.40 & 30.1 & 1.04 & 1.78 \\
10,000 & 15 & 1.01 & 30.2 & 0.97 & 1.80 \\
30,000 & 15 & 0.80 & 30.1 & 0.97 & 1.79 \\
105,000 & 15 & 0.18 & 28.2 & 0.96 & 1.51 \\
& 60 & 0.09 & 24.0 & 0.90 & 1.08 \\
\hline
\end{tabular}

* mg protein/ml plasma.

$\dagger \mu \mathrm{mol}$ phosphate/ml plasma.

$\ddagger$ nmol phosphate hydrolysed from ATP/mg protein $/ \mathrm{min}$.

\section{TABLE 2}

THE EFFECT OF GENTRIFUGAL FORCE ON CERTAIN GHARACTERISTICS OF BULL EPIDIDYMAL FLUID

\begin{tabular}{c|c|c|c|c}
\hline$R C F \times g$ & $\begin{array}{c}\text { Centrifuge } \\
\text { time (min) }\end{array}$ & $\begin{array}{c}\text { Absorbance } \\
\lambda=560\end{array}$ & Protein* & $\begin{array}{c}\text { Nucleotide } \\
\text { phosphatase }\end{array}$ \\
\hline 1,000 & 10 & 0.32 & 6.25 & 5.3 \\
& 30 & 0.09 & & \\
4,000 & 10 & 0.04 & 5.50 & $5 \cdot 1$ \\
& 30 & 0.02 & & \\
10,000 & 10 & 0.02 & 5.30 & 3.6 \\
30,000 & 30 & 0.01 & & \\
& 10 & 0.005 & 5.15 & $2 \cdot 8$ \\
\hline
\end{tabular}

* Single values per $\mathrm{RCF} \times \mathrm{g}$ represent pooled means for 10 - and 30 -min time intervals. Protein expressed as $\mathrm{mg} / \mathrm{ml}$.

$\dagger$ Activity expressed as $\mu \mathrm{mol}$ phosphate liberated from ATP/mg protein.

TABLE 3

THE EFFEGT OF GENTRIFUGAL FORGE ON CERTAIN GHARACTERISTICS OF BULL SEMEN

\begin{tabular}{c|c|c|c|c|c}
\hline$R C F \times \mathbf{g}$ & $\begin{array}{c}\text { Centrifuge } \\
\text { time (min) }\end{array}$ & $\begin{array}{c}\text { Absorbance } \\
\lambda=560\end{array}$ & Protein $^{*}$ & $\begin{array}{c}\text { Nucleotide } \dagger \\
\text { phosphatase }\end{array}$ & Phosphate $\ddagger$ \\
\hline 1,000 & 15 & $1 \cdot 263$ & $74 \cdot 6$ & 3470 & $4 \cdot 8$ \\
10,000 & 15 & 0.289 & $73 \cdot 3$ & 3470 & 4.8 \\
20,000 & 15 & 0.206 & $72 \cdot 1$ & 3220 & 4.8 \\
40,000 & 15 & 0.132 & $71 \cdot 3$ & 2550 & 4.6 \\
105,000 & 60 & 0.050 & $61 \cdot 3$ & 470 & $4 \cdot 2$ \\
\hline
\end{tabular}

* mg protein/ml plasma.

$\dagger$ nmol phosphate hydrolysed from ATP/mg protein $/ \mathrm{min}$.

$\ddagger \mu \mathrm{mol}$ phosphate/ml plasma. 
Bull epididymal fluid appears to contain only slight particulate contamination after centrifuging at $30,000 \mathrm{~g}$ (Table 2). Between 1000 and $30,000 \mathrm{~g}$ forces, a drop of over $1 \mathrm{mg}$ protein $/ \mathrm{ml}$ and of nearly $50 \%$ of the nucleotide phosphatase activity occurs.

Bull semen, like bull epididymal fluid, contains appreciable levels of the magnesium-stimulated nucleotide phosphatase (Tables 3 ). The activity of this enzyme drops over five-fold when centrifugation is at 105,000 g. Protein level declines 13 to $14 \mathrm{mg} / \mathrm{ml}$, and phosphate also declines with the $105,000 \mathrm{~g}$ centrifugation.

The results of this report definitely support the use of higher centrifuge forces in the study of semen composition. Substances supposedly in soluble form in semen have been shown to be partially pelleted at high centrifugal force. The male accessory glands are the source of particulate elements (Mann, 1964). Garbers et al. (1971) demonstrated that a magnesium-stimulated nucleotide phosphatase was associated with a light particulate fraction in epididymal fluid. These results indicate that the nucleotide phosphatase activity is not pelleted until very high centrifugal forces are used.

It is possible that some of the variability attributed to differences in semen composition between animals or between days is due to alterations in the amount of particulate matter being pelleted by lower centrifugal forces. For seminal plasma or epididymal fluid studies, a slow centrifugation to remove spermatozoa followed by a centrifugation at $105,000 \mathrm{~g}$ appears warranted. With the spermatozoa present, not only would a high centrifugation cause the spermatozoa to be contaminated by the particulate débris, but a considerable loss of sperm constituents would be expected (Mann, 1964).

Department of Meat and Animal Science Paper Number 576. The first author is a predoctoral trainee in the Endocrinology-Reproductive Physiology program at the University of Wisconsin supported by U.S.P.H.S. training grant No. 2-TO1-HD-00104-06. The authors are indebted to H. A. Lardy, at the Enzyme Institute, where most of these experiments were completed.

\section{REFERENCES}

Garbers, D. L., Wakabayashi, T. \& Reed, P. W. (1971) Enzyme profile of the cytoplasmic droplet from bovine epididymal spermatozoa. Biol. Reprod. (In press).

Hente, W. (1938) The specificity of some mammalian spermatozoa. F. Immunol. 34, 325.

LAYNE, E. (1957) Spectrophotometric and turbidimetric methods for measuring proteins. In Methods in Enzymology, Vol. III, p. 447. Eds. S. P. Colowick and N. O. Kaplan. Academic Press, New York.

Mans, T. (1964) The biochemistry of semen and of the male reproductive tract. John Wiley and Sons, New York.

SumNer, J. B. (1944) Scientific apparatus and laboratory methods: A method for the colorimetric determination of phosphorous. Science, $\mathcal{N} . r .100,413$. 